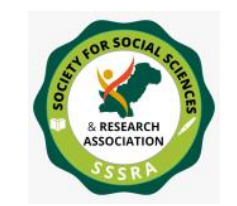

\title{
The Racial Conflict: Global Agenda in South Africa
}

\author{
Yumna Khatoon \\ Lecturer \\ Department of English \\ Federal Urdu University of Arts, Sciences \& Technology \\ Karachi - Pakistan \\ yumna.khatoon@fuuast.edu.pk
}

\begin{abstract}
:
Racism is global detrimental reality that has destroyed the peaceful social order in South Africa in the name of Colonialism and Imperialism by European countries from 1652-1961. The establishment of European colonial rule is shaped and developed by political conflicts of discrimination and segregation led towards socio-economic disparities due to difference in culture, language, religion and customs of Colonizer's minority and Colonized majority. The natives of South Africa were deterritoralized, disenfranchised and disposed of their land, identity and legal rights. The research analyzes the consequences of racism on social Cohesion creating endless historical conflicts. The research implies the theoretical framework of Derrick Bell's Critical Race Theory (CRT) to examine binary power relations in apartheid and post-apartheid South Africa. The research creates impartial analysis based on available facts to overcome the gap on the nexus between CRT implementation (American Origin) to the conditions of Blacks in South Africa. The research is Qualitative in approach to help out literary students of Social Sciences and Humanities to understand that history of racism and resilience remained same in different times in different countries to get liberated by despotic rule of European supremacy.
\end{abstract}

Keywords: Racism, Colonialism, Conflict, Apartheid, Binary power relation.

\section{Introduction}

"It is true that we should not forget where we come from, but we must be careful not to be held hostage by the past, to the detriment of harnessing new energies of progress which are unleashed by the new situation" (Mandela, 1998, p.187). 


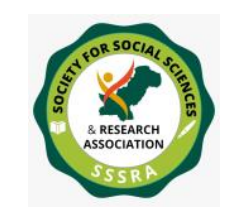

The Racial Conflict: Global Agenda ...

The global history witnessed that people around the globe resisted against particular political and socio - economic dichotomy that created binary power relations within a nation or in between two nations or states for possession of natural resources, raw material, cheap labor and territory. The thought of being subjected, subjugated and humiliated served as instinct for Societal conflicts basically ideological conflicts and racial conflicts. The history of Imperialism and Racism begun by Ship expeditions of Christopher Columbus across Atlantic Ocean in 1492. The Atlantic Slave Trade started in 16th century was an incentive to categorize human groups to justify slavery and indentured labor. The establishment of racial boundaries involved multifold factors for instance national origin, language, religion, culture, physical appearance and geographical traits. The history of South Africa is one of the historical narratives of colonized states by White dominance( Portugal, France, Britain) started in 1497 by Vasco de Gama's Portuguese expedition to Cape town. The arrival of Whites in South Africa as civilized, Christianized missionaries initiated social conflict of dispossession, deterritoralization and disenfranchisement of natives from their land and rights to obtain diamonds, gold, ivory, silk and minerals.

The White supremacism promoted racially segregated society in which social, political, economic rights were denied to natives of the South Africa specially Blacks and Colored natives Bantus. The Revised Oxford dictionary describes racism as human characteristics and abilities determined by race. Manuel Castells in The Power of Identity describes race as, "it is not merely political identity, but is something internalized and creates a certain consciousness in society" (Castells, 2013, p.7). Pattman focused on race as, "social phenomenon that binds a person to a particular group based on skin's color" (Benjamin, 2020, p.221). Edward Said elaborated the concept of Racism in Orientalism (1978) in terms of Orient (East) and Occident (West). It is a practical combination of investment in East to replicate general Culture, language, history and values of inferior race to justify superiority of West. Frantz Fanon in Black Skin, White Masks (1952) emphasized West cannot understand the ones who do not belong to it creating boundary of self and others. In The Wretched of the Earth (1961) Frantz Fanon asserted the fact racism is outcome of binary power relation between Colonized and Colonizers. One cannot be racist unless one has power to subjugate others. Therefore Racism is an ideology based on Segregation, discrimination, disintegration and degradation which takes the form of prejudice and antagonism towards disorder in society. In South African political system, racism is known as Apartheid that involved aspects of systematic Institutionalized Segregation embedded in social structure.

The rationale of this article is to lay bare the factors responsible for racial conflicts in South Africa in Apartheid period creating contemporary unchanged color 


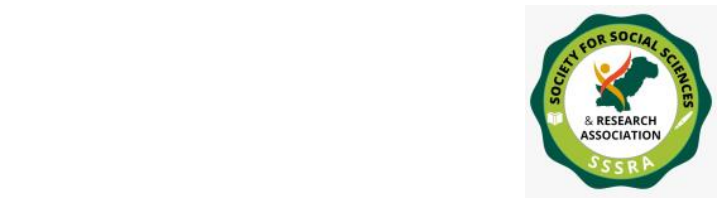

The Racial Conflict: Global Agenda ...

lines in Twentieth century. There is a knowledge gap on the symbiotic relationship between the concepts article examines as Binary power relation, racism and the Critical Race Theory. The present study examines CRT on basis of translating theoretical framework from original place America to South Africa as the conditions and situations of Blacks in both countries are same under subordination of Whites.

\section{Theoretical Framework}

The present study endeavors to evaluate the current body of research based on the Critical Race Theory (CRT). Historically CRT is a Global Social Theory begun to formulate a discourse that focused on issues of race, racism, law and binary power relations in society. The origin of CRT lies in Critical Legal studies (CLS) argues that despite Civil Rights Legislations the socio-economic conditions of Africans did not improve in America. CRT asserts that knowledge of the people of color is legitimate, appropriate and integral part to understand racial inequality and societal injustice. CRT is developed by Derrick Bell in 1972 with the book Race, Racism and American Law. CRT reached to culmination in contemporary times by the efforts of Richard Delgado and Jean Stefencic in the Critical Race Theory: Introduction (2001). According to Delgado and Stefencic, "races are products of social thought, relations and categories that society invents" (Delgado, 2001, p.7). Therefore CRT challenges and deconstructs the Eurocentric claims of neutrality in contemporary society. The research paper elaborates tenets of CRT as Permanence of racism and Interest convergence.

\section{Permanence of Racism}

Racism in South Africa is permanent and intractable since bygone eras of colonialism interconnected to contemporary racial development. South Africa is multiracial, multicultural and multilingual land of diversity. Historically socio-economic conditions of present South African society is imprinted in past, White supremacy and Black humiliation. Frederick Douglass published an article entitled as, The Color line in 1881, the phrase gained importance in the book of W. E. B. Du. Bois The Souls of the Black Folks in which he stated that, "The problem of the Twentieth century is the problem of the Color line, the relation of darker to the lighter races of men in Asia, Africa, America and the island of seas" (Bois, 1903, pp.10 - 29). The notion of Color line produced color discrimination and South Africans became victims of White minority throughout history. King John 11(1481-1495) was the king and royal authority of Portugal. He supported development and exploration of Africa and India during his reign for gold mines to double the royal revenues. Bartolomeu Dias was the first European navigator and Squire in court of king John 11 established trading station as fort namely 


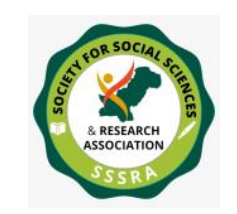

The Racial Conflict: Global Agenda ...

Cape Blanco at foreign territory of Africa that increased status quo of Portuguese nation as powerful trading nation. The Colonization of South Africa begun during 15th century when Portugal sailed ships to the Cape of Good Hope towards Indian Ocean for establishing their own trade monopoly in region and destroyed the Arab shipping.

During 1460s Portuguese came in contact with Kongo king Mbokani Mavinga who allowed slave trading activities with European nations in exchange of artilleries, cloth and luxuries. The ammunition enabled king to lay down factionalism and maintain dominant position in region. Millions of Africans were forcibly uprooted and displaced to South Africa to work as slaves on Sugarcane, tobacco, coffee and maize plantation developed by Portuguese. The world European trade resulted in Colonization of five continents over a period of five centuries. Each of the colonial power using military services dominated world trade at different times. When one colonial power became weak another challenged it and replaced it as leading Supreme power. European shipping nations stopped at the Cape of Good Hope to collect fresh water and food from Khoikhoi tribe in return of iron, alcohol and copper goods. The Dutch East India Company arrived in Cape Town in 1602 and marked permanent settlement in 1652. The slavery was continued till 1838 because there was shortage of labor on Wheat and vegetable farms. More than 35000 slaves were imported from India, Malaysia, Ceylon, Mozambique and Madagascar. The slaves have no personal rights regarded as possession for generations to work in fields and farms as indentured laborers.

To the indigenous people in South Africa the native land is symbol of sacredness and identity served as origin, essence and root for generations. The native land gives them sense of belonging, nourishment and livelihood. The native tribes used their culture and traditions for preserving the norms and resources of land alive. The first racial conflict appeared in series of war between Khoikhoi and Dutch settler from 1659-1660 and 1673-1677 over possession of native land. The Khoikhoi were dispossessed and deterritoralized from their origin lost their land, identity and integrity. Dutch laws, customs, language became ruling order of the day until Cape was dominated by the Great Britain in 1795. The British imperialist imperative came in racial conflict with native tribes Zulu, Xhosa, Matebele for territorial expansion and control of revenue generated by the lands. The Xhosa - British war (1779-1879) is the series of longest wars in history of South African colonialism over the issues of administration. The British High Commissioner of South Africa, Bartle Frere drawn the conflict into Britain's Confederation scheme and ignited the Xhosa war. The Xhosa indigenous people fought the war for the survival of ethnic strife. Their resistance is a response and reaction to disposition caused by the Great Britain. The brutal Xhosa war ended Black independence in South Africa. The British authoritarian power lethally captured the Xhosa territory and 


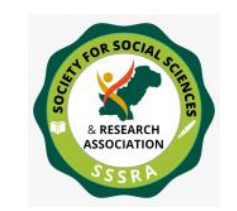

The Racial Conflict: Global Agenda ...

used for profit and power. The Britain strategy of intervention appeared in the Zulu kingdom and Matebele annexed to British Empire in 1843 as subordinate and inferior subjects to empire. Due to atrocities of the British imperialistic rule the mass migration the Great Trek occurred in 1795 till 1840 in which Dutch speaking inhabitants Boers migrated to interior of South Africa, inaccessible region to British administration. The British Empire decided to replace the colony's official language Afrikaans to English in 1830s.

The Great Trek was used as a narrative to promote Nationalistic sentiments. The postmodernist British cultural theorist Stuart Hall (1932-2014) in his essay Cultural Identity and Diaspora (1996) described two definitions of cultural identity. Firstly he stated as, "Cultural identity is stable, unchanging and continuous frame of reference and meaning. "Secondly he stated as, "Cultural identity undergoes constant transformation...subject to continuous play of history, culture and power" (Hall, 1973, p.15). Stephen Du Toit (1847-1911) Dutch church minister glorified the notion of Afrikaners in his newspaper Die Afrikaanse Patriot in 1876. The term became constant point of reference for Boers as cultural identity that imparts sense of identity defines by Hall in first definition. The term was influenced against anti- British sentiments, ideology, policies and customs to promote native sense of Oneness, Wholeness and belonging to land, language and culture. The discoveries of gold in Wit Watersand in 1886 revolutionized the fate of South Africa from agrarian country to largest gold producer in the world. Leonard Thompson in his book the History of South Africa stated, "The gold mining industry is both a boon and a potential cancer" (Thompson, 2001, p.136). White migration was attracted by Gold mining as a source of profit for investors and taxation for government but it deteriorates the status of black indentured labor living in poverty harsher. Meanwhile discovery of diamond in the Cape and Kimberly tripled the economy of colony and beneficiary was British Raj. The conflict of interest over gold and diamond mines between Boers and Britain ignited first Anglo- Boer war (18801881) and second Anglo-Boer war (1899-1902).

Richard Delgado and Jean Stefancic in the book Critical Race Theory cited, "dominant society realizes different minority groups at different times in response to shifting needs... at the same time group may appear... out of control require close monitoring and repression" (Delgado and Stefancic, 2001, p. 8). The Boers deprived of the ammunition, artillery and power to resist British troops supported by Canada, Australia, India and New Zealand agreed to come under the sovereignty of British crown and government. The Boers were repressed and monitored after peace agreement known as Treaty of Vereeniging (1902). Alfred Milner governor of Cape prescribed role of Blacks after treaty as, "the ultimate end is self-governing white community, supported by 


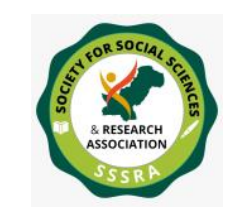

Pak. Journal of Int'L Affairs, Vol 4, Issue 2 (2021)

The Racial Conflict: Global Agenda ...

well-treated and justly governed black labor from Cape Town to Zambesi" (Thompson, 2001, p. 144). The Blacks were under strict control of Whites jingoistic spirit to create a boundless British territory from Cape to Zambesi by suppressing Black community. The prime Minister of Cape John X. Merriman passed the South African Act of 1909 unifying Colonies of Cape, Natal, Transvaal and Orange River Colony. In Encyclopedia Britannica it is written that colonial secretary Jan Smuts declared, "What we want is Supreme national authority to give expression to national will of South Africa and the rest is really subordinate". Jan Smutus used of we means White alone is the absolute authority in South Africa and all other races are really subordinates to White. Whites are civilized, humanized, enlightened missionaries who imparted nothingness, darkness and emptiness to subordinate colonial races. White regarded subordinate races as savage, brutes, uncivilized and inferior people. The mission of Colonial surge is to bring salvation and to develop minds of people with undeveloped hearts of Whites. The agents of whiteness became agents of darkness in South Africa. The Union Act was condemned by Blacks because the Union Act disenfranchised natives and imposed Segregationist laws including denial of voting rights and parliamentary representation. The Union enacted Natives Land act in 1913 and legalized racial discrimination for next nine decades. The land act prohibited Blacks for any purchase or lease of land outside reservation limiting black landownership to $7 \%$ and reserved $90 \%$ of land for hierarchical authority of Whites.

The founder of CRT Derrick Bell in book Faces at Bottom of Well: permanence of Racism said, "A society that produced a culture from whose inception racial discrimination has been a regulating force for maintaining growth and stability" (Bell, 1992, p. 34). Historically in South Africa White race produced a culture of demarcation and discrimination that is permanent having material determinism. Land laws limited Blacks outside the reserves to wage or tenant laborers for White farmers and ensured White autonomy in industries and rural township. After 1910 Blacks in reserve was unable to feed themselves and to pay taxes imposed by central and provincial governments. The hegemony of Whites appeared in propaganda of Pass Laws (1930) to restrict the mobility of African laborers from reserves to urban areas or vice versa. The Pass Laws dated back to 1841 Masters' and Slaves ordinance when slaves had to carry signed documents by their masters when they had to travel. The Pass permit acted as tool of identification for any African who entered urban area was to report official otherwise he would be jailed. In 1930, 42000 Africans were lawbreakers and jailed. The motif behind Pass Law is to get fixed the presence of Africans in the towns, mines, farms as labor having no voice, neither home nor rights and identity. The pervasive color bars and obsession of race made British supremacy as vital and essential in South Africa. 


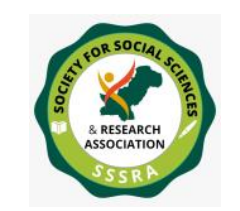

Pak. Journal of Int'L Affairs, Vol 4, Issue 2 (2021)

The Racial Conflict: Global Agenda ...

\section{Interest Convergence}

Interest convergence is critical tenet of CRT suggests that interest is divided by race origin. Black interest is subordinated by white interest hence interests never converge at one point. Derrick Bell argued that, "White self - interest will prevail over Black rights. This unstated but firmly followed principle has characterized racial policy decisions in society for centuries" (Bell, 1992, p., 42). Continued elevation of White monopoly of self - interest in South Africa is evidence that condition of Blacks is not distinct from the condition of enslaved past. The status of Blacks and Whites remained constant throughout history. The systematic racial realism of White community appeared in term of Apartheid (1856 - 1994). Apartheid is a policy that sanctioned racial Segregation and Socio-Political discrimination against non-white majority. Hendrick Verwoerd (1901 - 1966) was Prime Minister of colony, engineered the term Apartheid. Two nationalistic parties formed after establishment of Union of South Africa namely, National party (NP) for Whites and African National Congress (ANP) for Blacks. In 1948 $\mathrm{NP}$ won election on its Apartheid platform and entranced racial discrimination in state policy. The incidents are: firstly, enactment of Population registration Act (1950) which classified all South African as White, Black, colored (Asian, Xhosa, Zulu, Camissa, Khoisan, Griqua) races. Secondly, the enactment of Group Areas Act (1950) established business and residential sections for races. Thirdly, the enactment of Land Acts (1936) forced eviction of Africans from their land. Fourthly, the Bantu Authorities Act (1959) Homeland Citizen Act (1970) created ten African homelands made every Black citizen of Bantustan thereby excluding Blacks from national politics. Fifthly, the Prohibition of Mixed Marriages Act (1949) and the Immorality Act (1950) made interracial marriages and sexual relations illegal. Sixthly, the Bantu Education Act (1953) made African native education impossible to expand under provincial government. Seventhly, the White established separate educational, travelling, living standards till 1994. The national government established coercive Apartheid laws and executive actions to repress Black resistance. It includes the Unlawful Organization Act (1960), the Sabotage Act (1962), the Terrorism Act (1967) and the internal Security Act (1976). The law's enactment gave absolute powers to police to arrest people without charge and trial. The government can ban any organization and affiliation and prohibited General meetings.

Black rose up in protest against Apartheid in 1950s under the guidance of Nelson Mandela and Oliver Thambo. The Union of South Africa ended after referendum in 1960 in which majority voted for Republic of South Africa. In the outbreak of the World War 1 Prime Minister Louis Botha and Defense Minister Jan Smuts alleged to Britain but South African Army refused to fight against Germany because it was supplier of artillery in Anglo-Boer war. The revolt is known as Maritz Rebellion (1914-15) led by Manie 


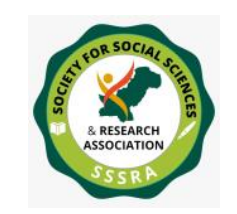

Pak. Journal of Int'L Affairs, Vol 4, Issue 2 (2021)

The Racial Conflict: Global Agenda ...

Maritz. Derrick Bell stated, "To realize with our slave forbearers that the struggle for freedom is at the bottom of our humanity that survives and grows stronger through resistance to oppression (Bell, 1992, p., 68). To resist oppression Black community employed a technique of Freedom charter in 1955 and opposed Apartheid. ANC presented the charter according to which South Africa belongs to all races, no particular group should have privileged life and all should be treated equally before law. ANC encouraged people to burn their passes and to refuse to use separate amenities. The boycott is non-violent strategy of Blacks but the White charged the delegates who announced Freedom Charter with treason and trial lasted for five years. In 1960 Africans at Sharpeville a Black township recorded their peaceful protest against Apartheid when police opened fire at the mob 69 killed and 250 wounded. On the wider circle in 1960s the Black Consciousness Movement was gaining momentum after Sharpeville incident. Steve Biko the founder of movement stated in, "Black consciousness is the essence, the realization by the black man of the need to rally together with his brothers around the cause of Subjection, the blackness of their skin, and to operate themselves from the shackles that bind them in perpetual servitude" ( Biko, 1979,p.,49). To reestablish the control of Black majority White used police brutality in another incident of Soweto riots (1976). Soweto protest is backed by Black Consciousness Movement who led 20,000 school children on demonstration against Afrikaans language in local schools. Police opened fire 500 died on spot estimated to 700. A series of continued riots and clashes broke out because state officials were unable to maintain peace and stability. Derrick Bell stated that, "to accept the reality that we live in a society in which racism is internalized and institutionalized" (Bell, 1992, p., 38).

UNO General Assembly passed resolution 392 and condemned the Soweto incident and Apartheid government. The UNO General Assembly suspended South Africa from UN Organization and ceased the sale of ammunition to South Africa. International events added pressure for domestic reforms for instance, in 1974 Portuguese dictatorship in Lisbon is overthrown and territories of Angola and Mozambique demanded independence. Zimbabwe got independence in 1980 which fueled the ANC and PAC to demand Self-government and independence. In Black Township both parties turned to violent adopted bombing strategies. They targeted police stations, power plants and administrative buildings all set ablaze. Mandela wrote a letter to Botha in which he stated, "White South African will simply have to accept that there will never be peace and stability until the principle of majority rule is fully applied" (Thompson, 2001, p. 245). In 1973, Black Wildcat trade union strikes broke out against injustice of White minority. Blacks were not allowed to form trade union as they have no leader to represent their issues. The value of South African currency shrink down and economy collapsed. South Africa was on verge of Civil War as ANC and PAC campaigned for urban terror. 


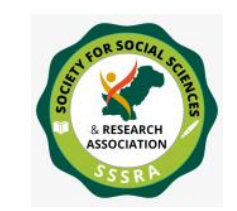

The Racial Conflict: Global Agenda ...

The Apartheid government declared emergency in state and Prime Minister Pietre Willem Botha resigned in 1989. F. W. D. Klerk was last Apartheid Prime Minister governed the country from 1989-1994. He opened the doors of cooperation and negotiations with Blacks freed Nelson Mandela after 27 years of imprisonment first and held democratic elections in 1994. He abolished Separate Amenities Act, Native Land Act and Group Areas Act and formed (CODESA) Convention for Democratic South Africa in 1991. In 1994 ANC won democratic elections and ended the racial realism of British Raj. Nelson Mandela became the driving force of democratic Republic of South Africa. He stated in presidential oath, "out of the experiences of extraordinary human disaster that lasted too long....never, never and never again shall it be that this beautiful land will gain experience the oppression of one by another" (Mandela, 1994, p.541).

The historic development of South Africa towards democracy is perilous path of resistance and resilience of Blacks that cannot summed up in few pages. The cultural pattern of oppression and perverted teaching of superiority infused in flux of Whites imparted racial Segregation at every level of society. Whites internalized and institutionalized racism that fostered hegemony of binary power relation. The subordination of Blacks gave satisfaction and contentment to Whites by imparting homelessness, uprootedness, powerlessness to Africans. Bonilla Silva in her book Invisible Weight of Whiteness declared major proponents of CRT which confirmed the Interest Convergence of Whites for material foundation in South Africa. She endorsed that, "Racism is embedded in structure of society. It develops and changes over different times. It has a contemporary approach also" (Silva, 2012, pp. 175 - 180). Historically racial hierarchies determine who constitutes the lion's share.

\section{Analysis}

The three hundred years of domination of White minority in South Africa destroyed the social Cohesion of society. The pivotal argument in the research is the deep rooted conflict marked by racial and political intolerance which widen the gulf of Apartheid in cultural and religious heritage despite of nonracial terminology of 1853 Constitution, it is ironical that Whites appeared as tyrannical rulers of colony. Prime Minister Cecil Rhodes in 1887 stated in parliament, "The natives is to be treated as a child and denied the franchise. We must adopt a system of despotism, such as works in India, in our relations with barbarism of South Africa" (Magubane, 1996, p. 108). The objective of Colonial conquest in South Africa is to construe a denigrated race based on inferior relations termed as barbarism in history. In South African society conflict is caused by the failure of government, institutions and colony to address the basic human necessities of individuals (majority) thus created frustration and aggression which led to 


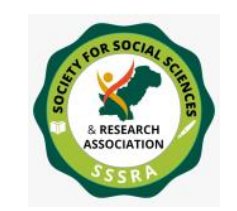

The Racial Conflict: Global Agenda ...

security threat. Thus the oppressed majority used non-violent behavior in form of social protest, civil disobedience and labor unrest which soon took the form of violent strategic behavior (destructive Conflict) of bombing and blazing government buildings and offices. The psychological effects of racism remained much same weather the colony remained in hands of Portugal or the Great Britain: marginalizing, denigrating and oppressive treatment. The dogma of decolonization and desegregation became the basis for liberation of humiliated classes. The life long struggle of Nelson Mandela, Oliver Thambo and Walter Sisulu secured Political freedom in which every individual is free for freedom of speech and opinion as are enjoyed by English people. The resistance and resilience for identity of Black Consciousness restored dignity and integrity. The task of newly formed democratic state is to transform a society molded by racism and colonialism. Derrick Bell in CRT asserted that, "contemporary color barriers are less visible but neither less real nor less oppressive" (Bell, 1992, p., 89). In 20th century people of British origin monopolized entrepreneurial zeal in every sector of economy in South Africa. Keith Gottschalk in 2019 published a blog named as, Race still colors South African politics 25 years after Apartheid's end in which he stated that White living standards have risen higher than since 1994. According to BBC survey in 2017 Black make up $80 \%$ of active population and hold only $14 \%$ of top management while $8 \%$ of Whites are $75 \%$ CEOS in listed companies. According to figures reported by (SAHR) South African human rights in 2018, 64\% of Blacks are living in poverty while unemployment rate is $36.5 \%$. The Democracy Index compiled by Economist Intelligence Unit in 2020 figured South Africa in Flawed Democracy chart which means the elections conducted in country is fair but having faults in governance. The aforementioned figures is a detrimental truth of modern age that Racism still prevails in South African society.

\section{Conclusion}

The basic tenets of Critical Race Theory: permanence of Racism and Interest Convergence have been addressed and analyzed. It is concluded that the consequences of racism in history of South Africa is a threat to Social Cohesion. The research evaluated that conflict management mechanism is still needed to address basic issues of political differences between Whites and Blacks in contemporary times. The binary power relation remained same with slightest differences in past and present. Moreover, South Africa requires the imperative of just peace after prolonged history of just war as a marshal plan of apartheid, segregation, discrimination and dislocation in the name of racism. 


\section{References}

Augustyn, A. (2016). South African Act (1909).

South Africa Act $\mid$ Definition, History, \& Facts | Britannica

Bell, D. (1993). Faces at the Bottom of the Well: Permanence of Racism. Basic New York.

Benjamin, N. (2020). Racism and Social Conflict Post 1994 in South Africa: A Conflict Resolution Perspective, 221. (PDF) Racism and Social Conflict Post-1994 in South Africa: A Conflict Resolution Perspective (researchgate.net)

Biko S. (1979). Black Consciousness in South Africa. Random House America, 79.

Bois, D., B., E., W. (1903). The Souls of the Black Folks. New American Library Press, 10-29.

Castells,M.(2013). The Power of Identity. The information Age: Economy, Society and Culture. Blackwell Oxford, 7.Delgado, R. and Stefancic, J. (2001). The Critical Race Theory: Introduction. New York University press, 7.

Hall,S.(2019). Identity and Diaspora volume 2. Duke University press Books, 15.

Magubane, M., B. (1996). The Making of Racist State: British Imperialism and the Union of South Africa. Africa Word press, 108.

Mandela, N. (1998). Struggle is My Life. Mayibuye Books South Africa, 187.

Mandela, N. (1994). Long walk to freedom. Back Bay Books, 541.

Silva, B. (2012). The Invisible Weight of Whiteness: The Racial Grammar of Everyday Life in Contemporary America, 175 - 180. The Invisible Weight of Whiteness: The Racial Grammar of Everyday Life in Contemporary America | Request PDF (researchgate.net)

Thompson, L. (2001). The History of South Africa. Yale University press London, 136. 